\title{
Perbaikan Kualitas Proses Produksi Karton Box Dengan Menggunakan Metode DMAIC Dan Fuzzy FMEA
}

\author{
Syarifuddin Nasution ${ }^{1}$, Renny Desiana Sodikin ${ }^{2}$ \\ Dosen Jurusan Teknik Industri ${ }^{1}$, Mahasiswa Jurusan Teknik Industri ${ }^{2}$ \\ Fakultas Teknologi Industri, Universitas Gunadarma \\ Jl. Margonda Raya No. 100, Depok 16424 \\ Email : synasution@staff.gunadarma.ac.id \\ Email : rennydesiana94@gmail.com
}

\begin{abstract}
Abstrak. Penerapan pengendalian kualitas dengan menggunakan metode atau aktivitas perbaikan kualitas bertujuan untuk mengurangi persentase produk cacat, sehingga produk yang dihasilkan memiliki kualitas yang baik sehingga keuntungan dan kepuasan pelanggan dapat tercapai. Metode penelitian yang digunakan bersifat case study pada PT. XYZ sebagai obyek penelitian, Data yang digunakan adalah data primer dan data sekunder mengenai jenis dan frekuensi kecacatan produk karton box dibagian converting. Penilaian dilakukan melalui pendekatan kuantitatif, yaitu dengan menganalisis pengendalian kualitas menggunakan metode DMAIC (Define, Measure, Analyze, Improve dan Control) dan fuzzy FMEA. Tujuan penelitian ini adalah untuk mengidentifikasi tingkat kecacatan dominan, menganalisis faktor penyebab kecacatan dominan serta usulan perbaikan guna peningkatan kualitas proses produksi karton box. Berdasarkan hasil identifikasi diperoleh kecacatan dominan terjadi pada proses produksi karton box adalah cacat cetakan yaitu sebanyak 109.439 unit (49,2 \%) dari total kecacatan yaitu sebanyak 222.421 unit. Penyebab kecacatan cetakan ada;ah: faktor manusia (kurangnya pengetahuan dan pelatihan terhadap mesin), faktor material (tinta kurang kental dan menggumpal), dan faktor mesin (penyumbatan anilox roll). Usulan perbaikan secara khusus adalah dengan membuat standar kerja untuk penyetelan jarak berdasarkan ketebalan sheet yang digunakan. Sedangkan usulan secara umum yang dapat dilakukan perusahaan untuk lebih meningkatkan kualitas produk adalah melakukan pelatihan operator mengenai pengoperasian mesin dan proses produksi di seluruh bagian terutama pada bagian converting.
\end{abstract}

Kata Kunci : Kecacatan, Pengendalian kualitas, karton Box, DMAIC, Fuzzy FMEA 


\section{Pendahuluan}

Pengendalian kualitas merupakan upaya dalam menjaga kualitas dari produk yang dihasilkan agar sesuai dengan spesifikasi produk yang telah ditetapkan berdasarkan kebijakan perusahaan. Secara teknis, pengendalian kualitas bertujuan untuk mengetahui apakah berjalan sesuai dengan rencana, telah dijalankan secara efisien atau belum serta memungkinkan atau tidaknya dilakukan perbaikan (Assauri, 2008). Saat ini, banyak konsumen yang tidak lagi memandang suatu produk hanya dari segi harga dan ketersediaan produk, tetapi juga kualitas dari produknya.

Permasalahan yang terjadi dalam proses produksi dapat berakibat pada kualitas produk akhir. Kualitas produksi akhir tersebut, dapat mengalami cacat atau tidak sesuai dengan standar produk yang telah ditentukan, sehingga dapat menyebabkan kualitas produk tersebut menjadi menurun. Salah satu perusahaan yang bergerak dibidang industri manufaktur, yang mengalami permasalahan produk cacat tersebut adalah PT. XYZ. Perusahaan ini, memproduksi karton box yang dalam pelaksanaan produksinya memiliki beberapa produk cacat terutama pada bagian cetakan, seperti produksi pada bulan Agustus 2016 sebesar 5.631.709 unit, dengan total produk cacat sebesar 222.421 unit.

Ada berbagai macam metode yang bermanfaat didalam pengendalian kualitas. Salah satunya dengan melakukan metode Define, Measure, Analyze, Improve dan Control (DMAIC). Metode DMAIC merupakan pendekatan yang lengkap untuk melakukan pengendalian dan perbaikan kualitas karena dimulai dengan mengidentifikasi masalah sampai melakukan pengendalian serta memberikan usulan untuk melakukan perbaikan (Susetyo, 2011; Caesaro et.al., 2015). Perbaikan yang dilakukan salah satunya adalah dengan menggunakan metode fuzzy FMEA. Metode Fuzzy FMEA didasarkan pada logika fuzzy yang sering digunakan sebagai alat untuk memanipulasi istilah linguistik yang digunakan secara langsung dalam membuat penilaian yang lebih kritis, yang nantinya akan digunakan untuk mementukan prioritas rencana perbaikan (Kusumadewi dan Purnomo, 2004).

Pengendalian kualitas yang baik perlu diterapkan, dengan menggunakan metode atau aktivitas perbaikan kualitas yang bertujuan untuk mengurangi presentase produk cacat, agar produk yang dihasilkan memiliki kualitas yang baik sehingga keuntungan dan kepuasan pelanggan dapat tercapai (Besterfield, 2006).

Berdasarkan latar belakang diatas, penelitian ini bertujuan untuk mengidentifikasi tingkat kecacatan dominan, menganalisis faktor penyebab kecacatan dominan serta usulan perbaikan guna peningkatan kualitas proses produksi karton box.

\section{Metode Penelitian}

Obyek yang digunakan dalam penelitian ini adalah proses pengendalian kualitas pada proses produksi dibagian converting. Data yang diamati hanya mengenai data kecacatan produk karton box dibagian converting.

\section{Variabel yang Diteliti}

Dalam penelitian ini variabel yang diamati adalah jenis-jenis kecacatan (frekuensi, persentase, total kumulatif) pada proses produksi bagian converting.

\section{Teknik Pengumpulan Data}

Metode Metode pengumpulan data / variabel yang digunakan dalam penelitian ini yaitu:

1. Observasi

Melakukan pengamatan secara langsung 
dan proses inspeksi dengan melakukan pengukuran terhadap dimensi produk.

2. Wawancara

Wawancara merupakan teknik pengumpulan data yang dilakukan melalui tatap muka dan tanya jawab langsung antara pengumpul data maupun peneliti terhadap narasumber atau sumber data.

3. Kuesioner atau angket

Digunakan sebagai alat pengumpulan data penelitian. Kuesioner terdiri dari daftar pertanyaan yang disampaikan kepada responden untuk dijawab secara tertulis.

\section{Tahapan Penelitian}

Dalam penelitian ini digunakan metode DMAIC terdiri dari 5 tahapan yaitu: tahap pendefinisian (define), tahap pengukuran (measure), tahap analisis (analyze), tahap perbaikan (improve) dan pengendalian (control) sebagai berikut :

- Tahap define dilakukan dengan mengidentifikasi permasalahan yang ada pada bagian produksi khususnya dibagian converting.

- Tahap measure, pada tahap ini dibuat diagram pareto untuk melihat kecacatan paling dominan, dan dilanjutkan dengan membuat peta kontrol $\mathrm{P}$, menghitung indeks kapabilitas proses dan menghitung nilai DPMO (Defect per million opportunities).

- Tahap analyze, merupakan tahap untuk menemukan penyebab permasalahan. Penyebab permasalahan tersebut dapat ditemukan dengan menggunakan diagram sebab-akibat. Penyebab masalah tersebut dapat diselesaikan dengan menemukan usulan yang tepat.

- Tahap improve, merupakan usulan perbaikan yang dapat diberikan pada perusahaan. Usulan perbaikan ini dapat diberikan dengan melakukan diskusi dan pembagian kuesioner penilaian FMEA kepada pihak-pihak terkait dan dilanjutkan dengan menggunakan metode FMEA (Failure Model and Effect Analysis) dengan pendekatan logika fuzzy FMEA (Failure Model and Effect Analysis) yang nantinya akan digunakan untuk mementukan prioritas rencana perbaikan.

- Tahap control, pada tahap ini hasil-hasil perbaikan atau peningkatan kualitas di dokumentasikan untuk dijadikan pedoman standar kerja guna mencegah masalah yang sama terulang kembali.

\section{Hasil dan Pembahasan}

\subsection{Tingkat Kecacatan Dominan}

Jenis kecacatan produk karton box pada proses converting terdiri dari 6 kategori. Kecacatan tersebut yaitu joint (no glue), krepek, sloter lari, cacat cetakan, layer rusak dan creasing pecah. Berikut ini adalah data jumlah cacat pada produk karton box di PT. XYZ pada bulan Agustus 2016.

\section{Tabel 1. Data Jumlah Kecacatan Karton}

Box

\begin{tabular}{|c|c|c|}
\hline No. & $\begin{array}{c}\text { Jenis } \\
\text { Kecacatan }\end{array}$ & $\begin{array}{c}\text { Jumlah } \\
\text { (Unit) }\end{array}$ \\
\hline 1 & Joint (No Glue) & 65.499 \\
\hline 2 & Krepek & 1.380 \\
\hline 3 & Sloter Lari & 4.277 \\
\hline 4 & Cacat Cetakan & 109.439 \\
\hline 5 & Creasing Pecah & 24.400 \\
\hline 6 & Layer Rusak & 17.426 \\
\hline \multicolumn{2}{|r|}{ Total Cacat } & 222.421 \\
\hline \multicolumn{2}{|r|}{ Total Produksi } & 5.631 .709 \\
\hline
\end{tabular}

Sumber: PT. XYZ, 2016

Berdasarkan Tabel 1, kemudian diukur karakteristiknya serta kapabilitas dari proses pada saat ini untuk menentukan langkah apa yang harus diambil untuk melakukan perbaikan dan peningkatan selanjutnya. Pengukuran ini meliputi pengolahan data pada diagram pareto, peta kontrol $\mathrm{P}$ dan 
DPMO (Defect Per Million Oppurtunities).

Tabel 2. Pengolahan Data Diagram Pareto

\begin{tabular}{|c|c|c|c|c|c|}
\hline No. & $\begin{array}{c}\text { Jenis } \\
\text { Kecacatan }\end{array}$ & $\begin{array}{c}\text { Frekuensi } \\
\text { (Unit) }\end{array}$ & $\begin{array}{c}\text { Total } \\
\text { Kumulatif }\end{array}$ & $\begin{array}{c}\text { Persentase } \\
\text { Kecacatan (\%) }\end{array}$ & $\begin{array}{c}\text { Persentase } \\
\text { Kumulatif (\%) }\end{array}$ \\
\hline 1. & Cacat Cetakan & 109.439 & 109.439 & $49,204 \%$ & $49,204 \%$ \\
\hline 2. & Joint (No Glue) & 65.499 & 174.938 & $29,448 \%$ & $78,652 \%$ \\
\hline 3. & Creasing Pecah & 24.400 & 199.338 & $10,970 \%$ & $89,662 \%$ \\
\hline 4. & Laver Rusak & 17.426 & 216.764 & $7,835 \%$ & $97,457 \%$ \\
\hline 5. & Sloter Lari & 4.277 & 221.041 & $1,923 \%$ & $99,380 \%$ \\
\hline 6. & Krepek & 1.380 & 222.421 & $0,620 \%$ & $100 \%$ \\
\hline \multicolumn{2}{|c|}{ Total Kecacatan } & 222.421 & & & \\
\hline
\end{tabular}

Berdasarkan perhitungan yang telah dilakukan pada tabel tersebut dapat dibentuk diagram pareto, seperti pada gambar berikut.

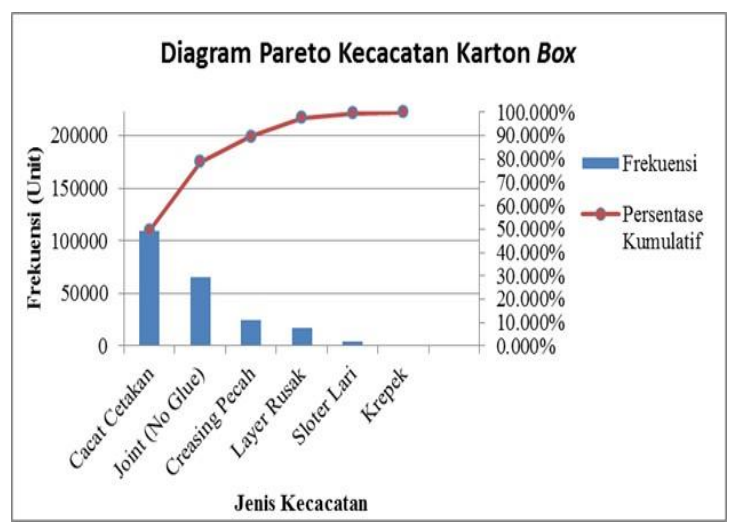

\section{Gambar 1. Diagram Pareto Kecacatan Karton Box}

Berdasarkan diagram pareto yang ditunjukan pada Gambar 1. menjelaskan bahwa cacat cetakan memiliki angka kecacatan tertinggi yaitu sebesar 109.439 unit, dengan persentase sebanyak 49,204\%. Kecacatan pada cetakan ini terjadi pada bagian converting karena pengaturan jarak antara silinder dies dan impression roll yang tidak sesuai, pengaturan kecepatan mesin yang tidak sesuai, pemasangan rubber dies yang tidak tepat, serta tersumbatnya saluran di anilox roll. Hal tersebut mengakibatkan kecacatan pada bagian cetakan seperti hasil cetak yang tidak solid, cetakan miring atau tidak sesuai dan adanya kotoran tinta pada bagian permukaan karton box. Kecacatan lain seperti joint (no glue), creasing pecah, layer rusak, sloter lari dan krepek disebabkan oleh ketidaksempurnaan proses pembuatan produk karton box pada bagian converting, ketidaksempurnaan tersebut diakibatkan dari berbagai faktor. Faktorfaktor tersebut antara lain seperti faktor manusia, material dan mesin.

\section{Peta Kontrol P}

Peta kontrol proporsi digunakan untuk mengukur proporsi ketidaksesuaian dari unit cacat yang sedang diinspeksi pada produk karton box. Proporsi kecacatan yang dipilih adalah cacat cetakan, karena cacat cetakan merupakan jenis kecacatan yang paling tinggi atau yang paling dominan terjadi dengan nilai frekuensi kecacatan sebesar 109.439 yang terjadi pada bagian converting. Berikut ini adalah proporsi cacat cetakan yang dapat dilihat pada Tabel 3.

\section{Tabel 3. Proporsi Kecacatan Cetakan}

\section{Karton Box}

\begin{tabular}{|c|c|c|c|}
\hline $\begin{array}{c}\text { Hari } \\
\mathrm{Ke}\end{array}$ & $\begin{array}{c}\text { Produksi Aktual } \\
\text { (Unit) }\end{array}$ & $\begin{array}{c}\text { Jumlah Cacat } \\
\text { (Unit) }\end{array}$ & $\begin{array}{c}\text { Proporsi } \\
\text { Kecacatan }\end{array}$ \\
\hline 1 & 122.575 & 2.304 & 0.018796655 \\
\hline 2 & 184.837 & 3.500 & 0.018935603 \\
\hline 3 & 191.409 & 3.645 & 0.019042992 \\
\hline 4 & 168.616 & 3.389 & 0.020098923 \\
\hline 5 & 222.680 & 4.192 & 0.018825221 \\
\hline 6 & 191.383 & 3.670 & 0.019176207 \\
\hline 7 & 154.336 & 3.141 & 0.020351722 \\
\hline 8 & 205.812 & 4.227 & 0.020538161 \\
\hline 9 & 229.844 & 4.223 & 0.018373331 \\
\hline 10 & 199.080 & 3.890 & 0.019539883 \\
\hline 11 & 255.910 & 5.240 & 0.020475949 \\
\hline 12 & 235.230 & 4.371 & 0.018581814 \\
\hline 13 & 273.890 & 5.067 & 0.018500128 \\
\hline 14 & 230.333 & 4.227 & 0.018351691 \\
\hline 15 & 236.807 & 4.387 & 0.018525635 \\
\hline 16 & 211.491 & 4.010 & 0.018960618 \\
\hline 17 & 220.276 & 4.507 & 0.020460695 \\
\hline 18 & 248.550 & 4.791 & 0.019275821 \\
\hline 19 & 210.250 & 4.248 & 0.020204518 \\
\hline 20 & 210.466 & 4.090 & 0.019433068 \\
\hline 21 & 262.556 & 5.010 & 0.019081644 \\
\hline 22 & 279.804 & 5.734 & 0.020492916 \\
\hline 23 & 293.761 & 5.994 & 0.020404342 \\
\hline 24 & 292.313 & 5.773 & 0.019749378 \\
\hline 25 & 299.500 & 5.809 & 0.019395659 \\
\hline Total & 5.631 .709 & 109.439 & 0.485572529 \\
\hline
\end{tabular}

Setelah menghitung proporsi dari kecacatan cetakan, langkah selanjutnya adalah menghitung nilai batas kontrol, batas kontrol atas UCL (Upper Control Line), dan batas kontrol bawah atau LCL ( Lower 
Control Line). Nilai tersebut akan dijadikan batas kontrol pada peta kontrol proporsi yang akan dibuat (Ariani, 2003). Berikut ini adalah contoh perhitungan batas kontrol pada hari pertama pengamatan.

$\mathrm{ni}=$ produksi aktual hari pertama $=$ 122575 Unit

$$
\begin{aligned}
\overline{\mathrm{p}} & =\text { jumlah cacat/produksi aktual } \\
& =109439 / 5631709=0,019432645 \\
\text { UCL } & =\overline{\mathrm{p}}+\sqrt{\frac{\mathrm{p} \times(1-\overline{\mathrm{p}})}{\mathrm{ni}}} \\
& =0,019432645+3 \sqrt{\frac{0,019432645 \times(1-0,019432645)}{122575}}=0,02061548 \\
\text { LCL } & =\overline{\mathrm{p}}-3 \sqrt{\frac{p \times(1-\overline{\mathrm{p}})}{\mathrm{ni}}} \\
& =0,019432645-3 \sqrt{\frac{0,019432646 \times(1-0,01943264)}{122575}}=0,018249807
\end{aligned}
$$

Berdasarkan hasil perhitungan batas kontrol atas UCL ( Upper Control Line), dan batas kontrol bawah atau LCL ( Lower Control Line), maka selanjutnya dapat dibentuk peta kontrol proporsi. Berikut ini adalah peta kontrol proporsi yang ditunjukan pada Gambar 2.

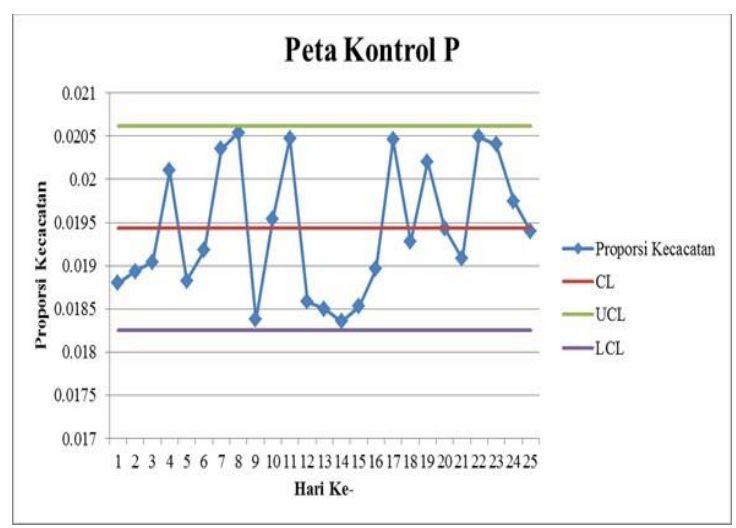

\section{Gambar 2. Peta Kontrol Proporsi Kecacatan Karton Box}

Berdasarkan Gambar 2 dapat dijelaskan bahwa proporsi kecacatan produk karton box berada didalam batas kontrol, hal tersebut memiliki arti bahwa semua data masih berada didalam kondisi terkendali. Suatu proses yang berada didalam kendali statistik, dapat dikatakan bahwa variasi yang terjadi dalam proses tersebut hanya diakibatkan oleh penyebab biasa dan bukan oleh penyebab khusus. Penyebab biasa dapat disebabkan dari berbagai macam faktor baik dari faktor manusia, mesin, material, metode dan lingkungan.

\section{DPMO (Defect Per Million Oppurtunities) \\ DPMO (Defect Per Million}

Oppurtunities) adalah jumlah kesempatan atau potensi yang dapat

mengakibatkan cacat (defect). Perhitungan ini bertujuan untuk mengetahui peluang terjadinya kecacatan jika terdapat satu juta kesempatan, perhitungan DPMO juga dapat mengetahui tingkat sigma untuk proses produksi karton box pada bagian converting yang di produksi oleh PT. XYZ. Berikut ini adalah perhitungan dari DPMO (Defect Per Million Oppurtunities).

Jumlah unit produksi $(\mathrm{U}) \quad=5.631 .709$

Jumlah cacat $(\mathrm{D}) \quad=222.421$

Peluang $(\mathrm{O}) \quad=4$

TOP (Total opportunities) atau total peluang adalah total terjadinya cacat didalam unit. Total peluang didapat dari hasil perhitungan dengan perkalian jumlah unit produksi dengan besarnya peluang kejadian terukur yang mungkin tidak terpenuhi spesifikasi batas dari karakteristik kunci kualitas CTQ (Critical to Quality) yang diinginkan oleh pelanggan terhadap hasil produksi. Total peluang yang dapat mengakibatkan tidak terpenuhi karakteristik kunci kualitas pada hasil produksi karton box adalah sebanyak 4, diantaranya adalah kesalahan operator saat mengatur kecepatan mesin, kesalahan operator pada saat mengatur jarak antara silinder dies dan impression roll, kesalahan operator dalam melakukan pemasangan rubber dies dan material cat yang kurang baik.

Berdasarkan hal tersebut, maka untuk 
nilai peluang $(\mathrm{O})$ bernilai 4 karena terdapat 4 penyebab potensial yang dapat mengakibatkan tidak terpenuhi karakteristik kunci kualitas. Berikut ini adalah perhitungan total peluang.

$$
\begin{aligned}
\text { TOP } & =\mathrm{U} \times \mathrm{O} \\
& =5631709 \times 4 \\
& =22.526 .836 \text { unit }
\end{aligned}
$$

Kemudian langkah berikutnya adalah menghitung cacat per unit (DPU). Hasil perhitungan cacat per unit didapat dari jumlah cacat (D) dibagi dengan jumlah unit produksi (U). Berikut adalah perhitungan cacat per unit pada produk karton box.

$$
\begin{aligned}
\text { DPU } & =\frac{\mathrm{D}}{\mathrm{U}} \\
& =\frac{222421}{5631709} \\
= & 0,03949441 \text { Cacat Per Unit }
\end{aligned}
$$

Langkah berikutnya adalah menghitung cacat per total kesempatan (DPO) yang merupakan peluang terjadinya kecacatan produk. Berikut ini adalah perhitungan cacat per total kesempatan.

$$
\begin{aligned}
\mathrm{DPO}= & \frac{\mathrm{D}}{\mathrm{TOP}} \\
= & \frac{222421}{22526836} \\
= & 0,0098736 \text { Cacat per Total } \\
& \text { Kesempatan }
\end{aligned}
$$

Berdasarkan hasil perhitungan DPO, maka dapat ditentukan nilai DPMO yang menunjukkan banyaknya cacat yang terjadi jika terdapat satu juta peluang. Berikut ini adalah perhitungan DPMO (Defect Per Million Oppurtunities).

$$
\begin{aligned}
\text { DPMO } & =\text { DPO x } 10^{6} \\
& =0,0098736 \times 10^{6} \\
& =9873,6 \text { Unit }
\end{aligned}
$$

Nilai DPMO menunjukkan kemungkinan kecacatan sebesar 9873,6 unit produk untuk satu juta produksi. Kecacatan tersebut merupakan suatu kerugian, karena semakin banyak produk yang cacat dalam proses produksi karton box maka akan berdampak pada pemborosan biaya produksi yang harus dikeluarkan oleh PT. XYZ.

Langkah berikutnya dilanjutkan dengan menghitung kapabilitas sigma. Nilai DPMO sebesar 9873,6 unit dapat dikonversikan menggunakan tabel konversi, sehingga didapat nilai sigma berada diantara DPMO 9642 dengan nilai sigma sebesar 3,84 dan DPMO 9903 dengan nilai sigma sebesar 3,83. Setelah itu dilakukan perhitungan interpolasi untuk mengetahui nilai sigma dengan DPMO sebesar 9873,6. Berikut ini adalah perhitungan interpolasi untuk mendapatkan nilai kapabilitas sigma.

Kapabilitas sigma

$$
\begin{aligned}
& =3,83+\frac{(9873,6-9642)}{(9903-9642)} \times(3,84-3,83) \\
& =3,839
\end{aligned}
$$

Kapabilitas sigma sebesar 3,839 nilai tersebut memiliki arti bahwa PT. XYZ melakukan kegiatan produksi yang cukup baik. Hal tersebut dapat dilihat dari cacat produksi yang dihasilkan masih berada didalam batas kontrol, namun perusahaan tetap harus selalu memperbaiki kesalahankesalahan yang ada atau mungkin terjadi guna mengurangi kuantitas dari produk cacat.

\subsection{Penyebab Kecacatan Dominan}

Analyze merupakan tahap menganalisa, mencari dan menemukan akar penyebab dari suatu permasalahan, pada tahap analisis ini dapat menggunakan diagram sebab akibat. Diagram sebab akibat digunakan untuk menunjukan faktor-faktor penyebab dan karakteristik kualitas (akibat) yang disebabkan oleh faktor-faktor penyebab itu 
(Gasperz, 2002).

Cacat cetakan merupakan prioritas utama pada perbaikan kualitas produk karton box, karena jenis cacat cetakan merupakan jenis kecacatan yang dominan terjadi pada produk karton box. Akar permasalahan dapat diketahui dengan menggunakan diagram sebab akibat. Berikut ini merupakan diagram sebab akibat yang ditunjukan pada Gambar 3.

\section{Gambar 3. Diagram Sebab Akibat Kecacatan Cetakan Karton Box}

Berdasarkan gambar tersebut dapat dijelaskan bahwa cacat cetakan memiliki faktor-faktor penyebab kecacatan yang terdiri dari faktor manusia, material, metode dan lingkungan. Faktor dan akar permasalahan dapat diketahui dengan melakukan wawancara kepada kepala bagian pengendalian kualitas, kepala regu pengendalian kualitas dan operatoroperator dibagian converting. Faktor yang pertama yaitu faktor manusia, pada proses converting ini manusia memegang tanggung jawab yang penting karena manusia yang mengendalikan, mengoperasikan dan mengatur jalannya proses produksi dengan penggunaan mesin.

Oleh sebab itu kecacatan yang terjadi pada produk karton box sebagian besar disebabkan oleh faktor manusia, seperti kurangnya pengetahuan terhadap mesin.
Kurangnya pengetahuan terhadap mesin ini disebabkan karena kurangnya pelatihan terhadap operator dalam pengoperasian mesin converting, kemudian kurangnya keterampilan disebabkan karena kurangnya pengalaman, penyebab lainnya yaitu kurangnya kontrol dari operator, seperti tinta yang kering serta kotoran yang menyumbat tinta yang disebabkan karena operator kurang teliti dalam melakukan

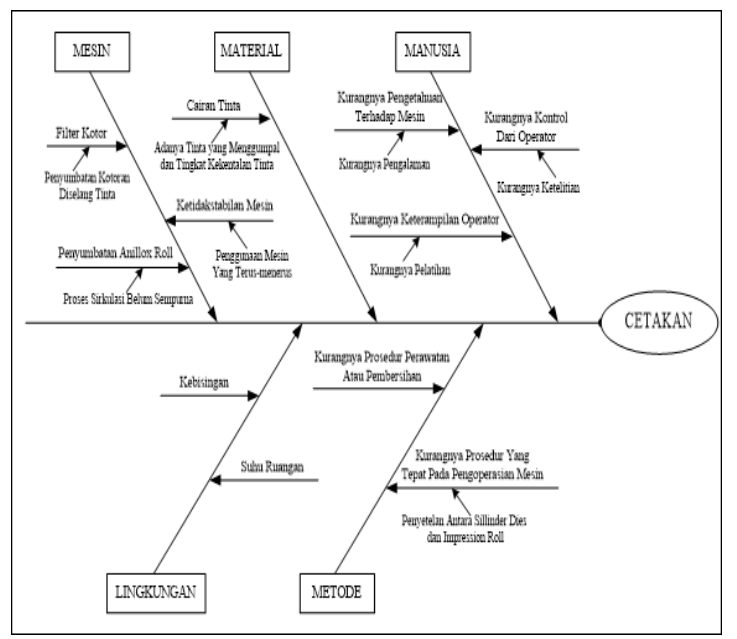

pengecekan komponen-komponen mesin converting.

Terdapat beberapa kekurangan dari mesin converting yaitu tidak mudah mengganti desain cetakan, mesin tidak dapat bekerja jika salah satu bagian mesin mengalami kerusakan, kerusakan yang terjadi harus dianalisa terlebih dahulu dengan menggunakan buku panduan mesin tersebut, mesin lebih rumit untuk diatur karena sistem yang digunakan sudah otomatis setiap komponen.

Faktor penyebab kecacatan cetakan yang kedua adalah faktor material. Faktor material yang mempengaruhi kecacatan cetakan adalah cairan tinta, terdapat cairan tinta yang kurang kental dan menggumpal. Hal tersebut disebabkan karena tidak adanya proses penyaringan tinta pada saat sebelum tinta dimasukan kebagian selang tinta.

Faktor penyebab kecacatan cetakan yang ketiga adalah faktor mesin. Penyebab yang pertama adalah filter kotor yang terjadi 
karena adanya penyumbatan dibagian selang tinta akibat belum digantinya dengan filter yang baru. Penyebab kedua yaitu penyumbatan anilox roll yang terjadi karena belum sempurnanya proses sirkulasi, hal tersebut menyebabkan tinta menjadi kotor. Penyebab yang ketiga adalah ketidakstabilan mesin, hal tersebut terjadi karena penggunaan mesin yang terus-menerus sehingga mengakibatkan mesin menjadi panas dan error.

Faktor penyebab kecacatan cetakan yang keempat adalah faktor metode. Penyebab pertama dalam faktor metode adalah kurangnya prosedur yang tepat pada sistem pengoperasian mesin. Hal tersebut dapat terlihat dari pemasangan tinta, belum tepatnya pengaturan jarak atau GAP antara tinta dengan sheet untuk tiap lot dalam proses converting. Penyebab yang kedua adalah kurangnya prosedur perawatan atau pembersihan tiap komponen mesin.

Faktor penyebab kecacatan cetakan yang kelima adalah faktor lingkungan, walaupun faktor lingkungan merupakan faktor penyebab kecacatan yang sangat kecil, namun tetap harus dianalisis secara menyeluruh. Penyebab pertama dalam faktor lingkungan adalah kebisingan, kebisingan ini terjadi akibat dari suara mesin-mesin yang sedang beroperasi. Kebisingan ini menjadi salah satu kendala karena mengakibatkan proses komunikasi yang terhambat. Penyebab kedua dalam faktor lingkungan adalah suhu ruangan, suhu ruangan di pabrik sekitar $30^{\circ}-34^{\circ} \mathrm{C}$. suhu ruangan yang panas dapat menyebabkan kurangnya daya tanggap terhadap intruksiintruksi yang diberikan karena dehidrasi, timbulnya kelelahan yang lebih cepat. Akan tetapi kondisi ruangan yang panas diperlukan dalam proses produksi karton box agar material utama yaitu kertas roll tidak mudah lembab.

\subsection{Usulan Perbaikan}

Improve merupakan tahapan untuk melakukan rencana dan usulan perbaikan. Rencana perbaikan dapat dilakukan dengan berbagai cara, salah satunya yaitu dengan menggunakan metode FMEA (Failure Mode and Effect Analysis) dengan pendekatan logika fuzzy, fuzzy FMEA ini nantinya akan digunakan untuk mementukan prioritas rencana perbaikan (Yeh dan Hsieh, 2007; Marimin, 2013; Nasution et al, 2014).

FMEA adalah perbaikan dari aktivitas yang mengidentifikasi dan mengevaluasi tingkat kegagalan potensial yang terjadi pada produk atau proses produksi pembuatan produk karton box. Penilaian FMEA dapat diberikan dengan melakukan disikusi dan pembagian kuesioner kepada pihak-pihak terkait. Berikut ini merupakan hasil dari FMEA konvensional yang ditunjukan pada Tabel 4.

\section{Tabel 4. FMEA Konvensional}

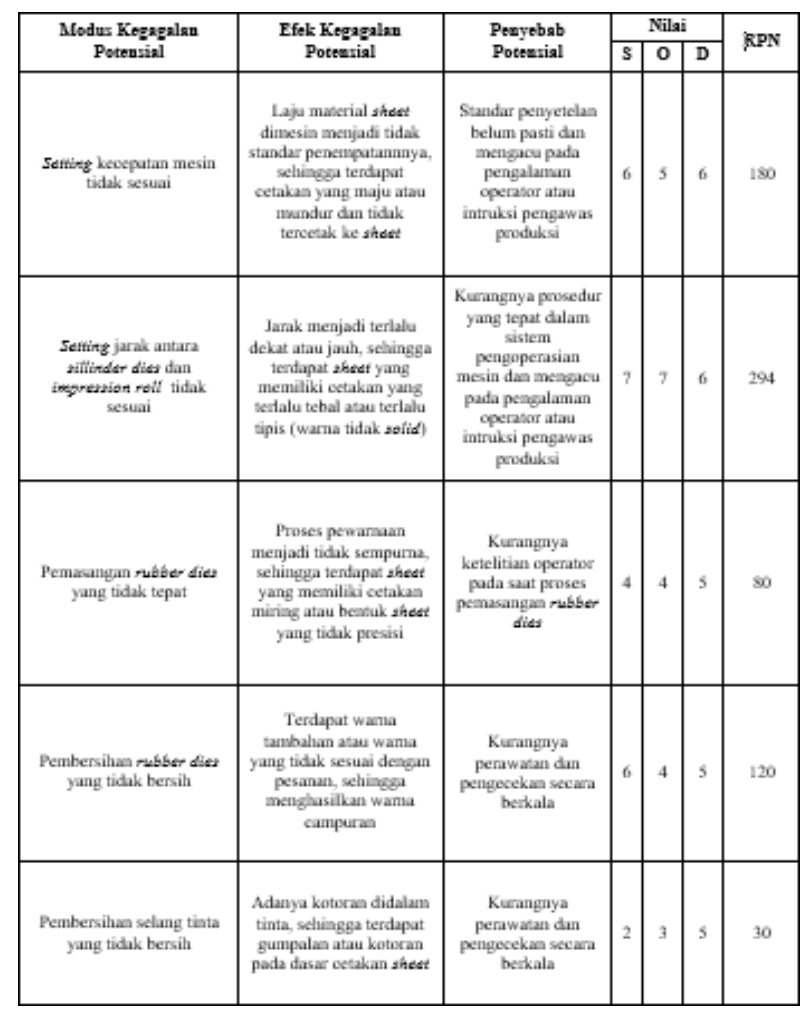


Dari Tabel 4 diatas dapat dilihat bahwa RPN (Risk Priority Number) memiliki nilai yang berbeda-beda. RPN itu sendiri digunakan sebagai penerjemah sekumpulan dari efek dengan tingkat keparahan (severity) yang serius, sehingga dapat menciptakan suatu kegagalan yang berkaitan dengan efek tersebut (occurance) dan mempunyai kemampuan untuk mendeteksi kegagalan-kegagalan (detection). Nilai S, O dan $\mathrm{D}$ didapat dari diskusi dan penilaian yang dibuat melalui kuesioner yang dibagikan kepada pihak- pihak terkait (Rusmiati, 2014; Crysler, 2008).

RPN yang memiliki nilai tertinggi yaitu sebesar 294 dengan modus kegagalan potensial mengenai setting jarak antara sillinder dies dan impression roll. Nilai RPN tertinggi memiliki severity sebesar 7 , occurance sebesar 7 dan nilai dection sebesar 6. Kemudian proses selanjutnya adalah melakukan pengolahan fuzzy FMEA dengan pendekatan logika fuzzy. Proses fuzzifikasi menggunakan MATLAB 7.11.

Dari Tabel 5 diatas dapat dilihat bahwa RPN (Risk Priority Number) memiliki nilai yang berbeda-beda. RPN dengan nilai tertinggi dapat digunakan sebagai prioritas penanggulangan yang serius.

RPN yang memiliki nilai tertinggi diurutan pertama yaitu sebesar 294 dengan modus kegagalan potensial mengenai setting jarak antara sillinder dies dan impression roll. FRPN tertinggi diurutan pertama sebesar 479 dengan modus kegagalan yang sama seperti RPN tertinggi yaitu mengenai setting jarak antara sillinder dies dan impression roll tidak sesuai, dengan kategori tinggi. Rekomendasi penanggulangan pada masalah mengenai setting jarak antara

\section{Tabel 5. Perbandingan FMEA} Konvensional dengan Fuzzy FMEA

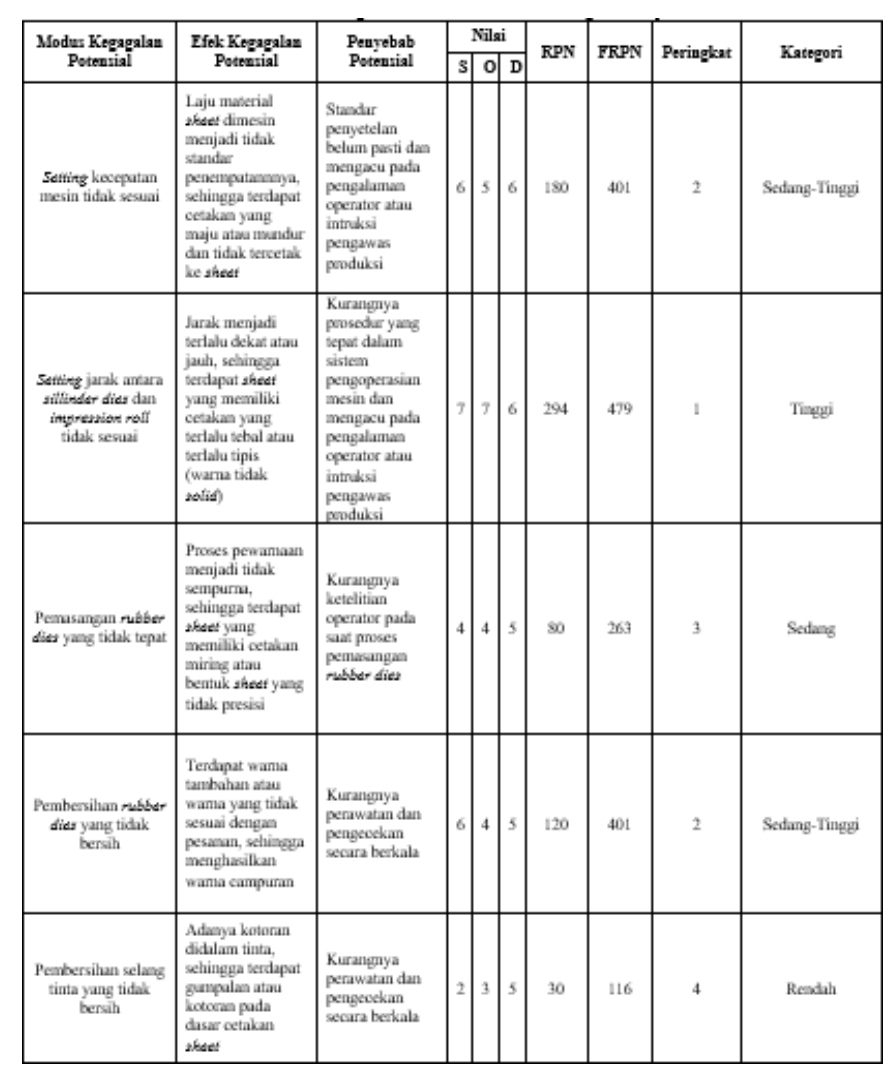

RPN itu sendiri digunakan sebagai penerjemah sekumpulan dari efek dengan tingkat keparahan (severity) yang serius, sehingga dapat menciptakan suatu kegagalan yang berkaitan dengan efek tersebut (occurance) dan mempunyai kemampuan untuk mendeteksi kegagalankegagalan.

sillinder dies dan impression roll tidak sesuai adalah dengan membuat standar kerja untuk penyetelan jarak berdasarkan ketebalan sheet yang digunakan.

Terdapat perbedaan nilai yang ditunjukan antara RPN dan FRPN, hal ini disebabkan karena perhitungan RPN hanya dilakukan dengan menganalisa dan mengalikan S, O dan D saja tanpa memperhatikan derajat kepentingan setiap input yang ada. Sedangkan nilai FRPN diperoleh melalui hasil fuzzifikasi. Pada proses fuzzifikasi 
terdapat aturan-aturan yang mengutamakan penanganan masalah lebih kepada penyebab dari cacat yang terjadi, dengan nilai yang memperhatikan derajat kepentingan setiap input yang diberikan.

Control atau tahap pengendalian merupakan tahapan terakhir dari metode DMAIC. Tahap pengendalian yaitu pengendalian dan pengawasan terhadap rencana perbaikan yang direkomendasikan atau diusulkan untuk di realisasikan di perusahaan dengan harapan dapat mengurangi penyebab kesalahan yang dapat menimbulkan kecacatan produk.

Pengendalian ini sepenuhnya adalah wewenang perusahaan untuk merealisasikan rekomendasi penanggulangan atau rencana perbaikan. Berikut ini ada beberapa rencana perbaikan yang direkomendasikan untuk mencegah permasalahan yang sama datang kembali.

1. Melakukan pelatihan operator mengenai pengoperasian mesin dan proses produksi di seluruh bagian terutama pada bagian converting, pelatihan ini harus benar-benar dipahami oleh operator untuk mengurangi penyebab kesalahan yang mengakibatkan produk cacat. Operator sebaiknya mengikuti dan menerapkan SOP yang ada di perusahaan.

2. Melakukan perawatan mesin secara khusus atau membuat urutan perawatan komponen, mengadakan pergantian part jika komponen atau part sudah rusak. Perawatan mesin secara khusus sebaiknya dilakukan minimal 2 minggu sekali, sehingga dapat mengurangi penyebab kesalahan yang dapat menyebabkan kecacatan produk yang dihasilkan.

3. Inspeksi sheet secara teliti sebelum proses converting, membuat standar kerja untuk penyetelan jarak berdasarkan ketebalan sheet yang digunakan, meningkatkan koordinasi antar pekerja, melakukan pengawasan secara rutin dan acak untuk melihat kinerja operator, serta memberikan pengarahan yang jelas ketika terjadi kesalahan.

\section{Kesimpulan}

Berdasarkan pembahasan dan analisis yang telah dilakukan, maka dapat dibuat kesimpulan sebagai berikut:

1. Jenis kecacatan yang paling dominan terjadi pada proses produksi karton box adalah cacat cetakan yaitu sebanyak 109.439 unit atau sebesar 49,2\% dari total kecacatan yaitu sebanyak 222.421 unit.

2. Penyebab terjadinya kecacatan cetakan yang terjadi pada produk karton box sebagian besar disebabkan oleh faktor manusia (seperti kurangnya pengetahuan terhadap mesin, pelatihan, serta kontrol dari operator). Faktor material yang mempengaruhi kecacatan cetakan adalah cairan tinta (kurang kental dan menggumpal). Faktor mesin yang mempengaruhi kecacatan cetakan penyumbatan anilox roll yang terjadi karena belum sempurnanya proses sirkulasi, hal tersebut menyebabkan tinta menjadi kotor. Penyebab selanjutnya adalah ketidakstabilan mesin, hal tersebut terjadi karena penggunaan mesin yang terus-menerus sehingga mengakibatkan mesin menjadi panas dan error.

3. Guna meningkatkan kualitas produk yang dihasilkan berdasarkan pendekatan DMAIC dengan menggunakan metode fuzzy FMEA adalah fokus ke modus kegagalan potensial mengenai setting jarak antara sillinder dies dan impression roll. Usulan perbaikan secara khusus adalah dengan membuat standar kerja untuk penyetelan jarak berdasarkan 
ketebalan sheet yang digunakan. Usulan secara umum yang dapat dilakukan perusahaan untuk lebih meningkatkan kualitas produk adalah melakukan pelatihan operator mengenai pengoperasian mesin dan proses produksi di seluruh bagian terutama pada bagian converting. Melakukan perawatan mesin secara khusus, meningkatkan koordinasi antar pekerja dan melakukan pengawasan secara rutin.

\section{DAFTAR PUSTAKA}

Ariani, D Wahyu. 2003. Pengendalian Kualitas Statistik. Yogyakarta: Andi. Chodariyanti.

Assauri, Sofyan. 2008. Manajemen Produksi. Edisi Revisi. Jakarta: FE UI.

Besterfield, Dale. 2006. Total Quality Management. New Jersey: Prentice Hal.

Caesaro, Dino., Simatupang, Stenly Yohannes P. 2015. Implementasi Pendekatan DMAIC Untuk Perbaikan Proses Produksi Pipa PVC (Studi Kasus PT. Rusli Vinilon). Jakarta: Universitas Bunda Mulia.

Chrysler LLC. (2008). Potential Failure Mode And Effects Analysis. Ford Motor Company, General Motors Corporation. Dalam Jurnal Rusmiati, Emi. 2014. Penerapan Fuzzy Failure Mode And Effect Analysis (FUZZY FMEA) Dalam Mengidentifikasi Kegagalan Pada Proses Produksi Di PT Daesol Indonesia. Jakarta: Sekolah Tinggi Manajemen Industri. Gaspersz, Vincent. 2002. Pedoman Implementasi Program Six Sigma Terintegrasi Dengan ISO 9001:2000, MBNQA, DAN HACCP. PT. Gramedia Pustaka Utama.

Kusumadewi, Sri dan Purnomo, Hari. 2004. Aplikasi Logika Fuzzy Untuk
Pendukung Keputusan. Yogyakarta: Graha Ilmu.

Marimin. 2013. Teknik Dan Analisis Pengambilan Keputusan Fuzzy Dalam Manajemen Rantai Pasok. Bogor: IPB Press.

Nasution S, Arkeman Y, Soewardi K, Djatna T. 2014. Identifikasi dan Evaluasi Risiko Menggunakan Fuzzy FMEA pada Rantai Pasok Agroindustri Udang. Jurnal Riset Industri. Vol. 8. No. 2. Agustus 2014. Rusmiati, Emi. 2014. Penerapan Fuzzy. Failure Mode And Effect Analysis (FUZZY FMEA) Dalam Mengidentifikasi Kegagalan Pada Proses Produksi Di PT Daesol Indonesia. Jakarta: Sekolah Tinggi Manajemen Industri Manajemen Rantai Pasok. Bogor: IPB Press.

Susetyo, Joko. 2011. Aplikasi Six Sigma DMAIC Dan Kaizen Sebagai Metode Pengendalian dan Perbaikan Kualitas Produk. Jurnal Teknologi. Volume 4 No.1 61-53. Institut sains \& Teknologi AKPRIND, Yogyakarta.

Yeh RH, Hsieh MH. 2007. Fuzzy assessment of FMEA for a sewage plant. Journal the Chinese Institute of Industrial Engineers. 24: 505-512. 